\title{
Can the revised UK Code direct practice?
}

\author{
Post-refereed author's version. This paper has been accepted for \\ publication in Nursing Ethics http://nej.sagepub.com/
}

\begin{abstract}
The Nursing and Midwifery Council, the United Kingdom regulator of nursing and midwifery has recently revised its professional code of practice. This paper begins by arguing that a professional code must be capable of sustaining close reading and of action guidance. Using four exemplar clauses it is argued that the new revised code does not met this purpose. First, I show that in setting out requirements for consent and documentation, the meaning of the relevant clause has changed significantly during the editing process so that a literal reading of the final document bears little relation to established professional practice. Second, I argue that the clause concerning the nature of professional relationships has also been altered during the editing process so that it is inconsistent with other professional groups and established accounts of the professional nurse-patient relationship. Third, I argue that the clause concerning disclosure of confidential information, which survived revision and editing with its meaning intact is nevertheless factually incorrect and inconsistent with UK law and authoritative guidance. Finally, fourth, I argue that use of the word 'inappropriate' is inappropriate as it amounts to meaningless circularity, discussed in relation to a clause on expressing personal beliefs. Taken together, these examples demonstrate that the Code is seriously flawed and does not fulfil its purpose. One way that simple prescriptive clauses in the Code can be usefully understood is through the provision of detailed guidance. I argue that the NMC has changed its position on its view of the value of guidance and has significantly reduced the amount of written guidance and advice is provides. The paper concludes by arguing that in order to meet its action directing function, further clarifying revision and the provision of detailed guidance is required.
\end{abstract}

Keywords: Professional regulation, Code of conduct, confidentiality, professional relationships

Dr Paul Snelling

Principal Lecturer in Adult Nursing

University of Worcester

Institute of Health and Society

Henwick Grove

Worcester

WR2 6AJ

उ. 01905542615

D.snelling@worc.ac.uk 


\section{Introduction}

Professional codes of conduct fulfil many functions. Though they cannot generally be regarded as helpful guides to resolve the ethical dilemmas that nurses and midwives regularly encounter, they must be clear enough so that nurses understand what their professional practice demands of them, so that educators can use the text and associated guidance to facilitate students' understanding of the nature of professional practice, and so that regulators can use them to police entry and maintenance on a professional register. Following consultation, the Nursing and Midwifery Council (NMC), the United Kingdom (UK) regulator for nursing and midwifery has recently revised its code [1], and the aim of this discussion paper is to evaluate its effectiveness as a guide to practice and a learning resource.

In a sense this paper follows in the tradition of trenchant critiques of previous versions [2,3], but its scope is narrower. I argue that in order to fulfil its function the Code must be capable of withstanding critical scrutiny and a literal reading, finding support for this view from the Code introduction and literature written by a senior figure at the NMC. The paper is not a line by line dissection of the whole document, nor a structured documentary analysis, but using close reading of four exemplar clauses I argue that that the Code fails to meet its stated function. First, I show that in setting out requirements for consent and documentation, the meaning of the relevant clause has changed significantly during the editing process so that a literal reading of the final document bears little relation to established professional practice. Second, I show that the clause concerning the nature of professional relationships has also been altered during the editing process so that it is inconsistent with other professional groups and established accounts of the professional nurse-patient relationship. Third, I argue that the clause concerning disclosure of confidential information, which survived revision and editing with its meaning intact is nevertheless factually incorrect and inconsistent with UK law and authoritative guidance. Finally, fourth, I argue that use of the word 'inappropriate' is inappropriate as it amounts to meaningless circularity, discussed in relation to a clause on expressing personal beliefs. Taken together, these examples demonstrate that the Code is seriously flawed.

Complex professional practice cannot be fully captured by a series of statements in professional codes [4], and one way that this can be addressed is by regulators providing detailed explanatory guidance, a feature of codes from other UK professional health care regulators and nursing regulators around the world. The NMC, however, has chosen to reduce significantly the amount of guidance and advice that it provides and so nurses must make their own arrangements to interpret ambiguous clauses in the Code. Drawing on NMC documentation, I argue that the NMC position on providing guidance is also flawed and contradictory, and I conclude by arguing that in order to provide an effective regulatory framework which also guides and educates, the NMC Code is in need of further corrective revision, and detailed guidance consistent with that provided by other UK regulators should be provided. Though this paper offers detailed analysis of the UK situation, the regulatory environment is similar throughout the world, and arguments made here are of wider interest.

\section{Development of the new code}

High profile failures of care at Mid Staffordshire NHS Trust resulted in detailed enquiries undertaken by a prominent lawyer, Sir Robert Francis [5,6]. Though Francis found that the 
Code had the merit of 'clarity and simplicity' [6, p.1040] the NMC undertook to review the existing code (v1 [7]) in light of his recommendations as part of its response to the second report [8]. After an initial round of consultation, a draft revised version (v2 [9]) was released for further wider consultation, and subsequently a report [10] was published detailing the consultation evidence. A final and substantially different draft (v3 [11]), accompanied by an explanatory paper [12] was presented and approved at the Nursing and Midwifery Council ${ }^{\mathrm{a}}$ meeting of $3^{\text {rd }}$ December 2014. Following this meeting the Code was further edited in order to comply with plain english standards with the intention of being granted the 'Crystal Mark' [13] awarded by the Plain English Campaign. The minutes of the meeting [14] note that providing the edits were minor, approval of the final iteration, that is the published version [1], could be delegated to the Chair and the Chief Executive. The revised version has additional sections on the duty of candour, fundamental care, social media, medicines management, end of life care and conscientious objection, and revisions to sections on compassion, teamwork, record keeping, delegation, raising concerns and co-operating with investigations and audits $[15,16]$.

The final published code is organised around four themes (prioritise people, practice effectively, preserve safety, and promote professionalism and trust). Following the titles of each section a short explanatory paragraph written (in the main) in descriptive terms is addressed to registrants (for example: you put the interests of people using or needing nursing or midwifery service first). There are a total of 25 statements, under just three of which (numbers 5, 10 and 23) follows a short explanation. After this the words 'To achieve this, you must:' are followed by a series of numbered clauses, or 'sub-statements' that 'add clarity to the requirements of the overarching statement' [12, p.4].

\section{How should a code be read?}

The method of reading text varies depending on its form, context, and intended audience. I always read a thriller more quickly than a literary novel, quicker again than a poem where every word and line is savoured. In information giving literature, the general gist is often enough; people need to know (for example) to call an ambulance for a suspected stroke but need not be concerned about whether the patient fits precise criteria, and they will not be taken to task if they call as the result of a mistaken belief. In contrast, within legal practice, philosophy and theology, single words, phrases and sentences are pored over to establish precise meaning, since substantially different courses of action can follow differing interpretation. How then are we to read a professional code of conduct?

A good place to start to answer this question is to ask who it is written for and for what purpose. Helpfully, this information is provided on the first two pages of the latest iteration of the NMC Code. Though addressed to registrants, it is also written for patients and service users, employer organisations, educators and students. In particular, 'nurses and midwives can use it to promote safe and effective practice in their place of work' and 'educators can use the Code to help students understand what it means to be a registered professional and how keeping to the Code helps to achieve that' [1, p.3]. It is an 'essential guide' for new

\footnotetext{
${ }^{a}$ In the NMC Governance structure, the Council as the Board of Trustees is the governing body, analogous to a Board of Directors in a commercial organisation. It has twelve members, appointed by the Privy Council six of whom are registrants. There is potential for confusion about the word 'Council'. To be clear I use 'Council' to mean the Governing Council of the Nursing and Midwifery Council.
} 
nursing students [17] and this aim alone requires clarity in language if students are to learn what their regulator requires of them [18]. Precision is also required because at fitness to practice hearings the conduct of accused nurses, and potentially their future in the profession is measured against what the Code mandates. During consultation, the Royal College of Nursing (RCN) [19] expressed concern that a poorly constructed code would overwhelm the NMC with fitness to practice cases, and in its response to a Law Commissions consultation on the regulation of health care professionals, the NMC conceded that:

The contract between a regulator and its registrants demands that registrants have a right to clarity about which aspects of practice are critical to their continued registration.

In an editorial in the Journal of Community Nursing, Katerina Kolyva, who as director of continued practice at the NMC is responsible for standards states that '[The Code] sets out the fundamental standards of nursing and midwifery practice explaining exactly what nurses and midwives must do to justify the trust that patients place in those who care for them' [21, emphasis added]. The word 'exactly' is important here as is the word 'must' which also prefaces clauses in the Code indicating their directive nature. The introduction to the Code states that while "you can interpret the values and principles set out in the code in a range of different practice settings, they are not negotiable or discretionary' [1, p2]. The analysis of this paper proceeds on the premise that professional codes of conduct and the clauses within them must be able to withstand close critical and literal reading so that their meaning is clear, capable of directing action and consistent with other important documents. This initial premise is important as the arguments contained in this paper are generated directly from it. Some may regard the detailed textual citation as linguistic nit picking but this would be a superficial evaluation. A serious critic of my conclusions will need to show that either this initial premise or my close reading of clauses is mistaken.

\section{What's in a name?}

It is curious, though probably not material, that the full name of the Code was changed after consultation, though without a reason being given. In noting the omission of the word 'ethics' from the title and text $\mathrm{t}^{\mathrm{b}}$, Bradshaw [22] finds it strange that ethics is no longer considered fundamental. However, dropping the word 'ethics' could be justified since the Code is much more a legal document than an ethical one, telling registrants not what they ought to do but what they must do. The title change from 'Standards of conduct, performance and ethics...' to 'Professional standards of practice and behaviour...' is also of interest as the word 'behaviour' is seldom seen in regulatory codes. A Law Commissions report [23, p.36] notes a legal judgement ${ }^{\mathrm{c}}$ which acknowledged the regulators' objective of 'declaring and upholding proper standards of conduct and behaviour', and the inclusion of both words clearly implies that they are not exactly synonymous. A board paper presented to the Council detailing plans for reviewing standards and guidance [24] notes that the new Code was provisionally entitled 'Good Nursing and Midwifery Practice', echoing the title of the General Medical Council's (GMC - the UK medical regulator) regulatory document, 'Good Medical Practice' [25]. This

\footnotetext{
${ }^{\mathrm{b}}$ The word 'ethical' appears in the new Code just once in relation to advertisements or published material ([1],Clause 21.4)

${ }^{\mathrm{c}}$ Cohen v General Medical Council [2008] EWHC 581(admin) [2008] LS Law Medical 246at [62]
} 
'provided the most relevant information in the current regulatory environment' [10, p.3] during the review of other UK regulators' documents which informed development of the new code. This and other changes are of semantic interest but there are a number of areas where changes to the Code have produced clauses which contradict established professional practice and/or are ambiguous, and given the stated requirements of exactitude, directive power and educative purpose, this may have adverse consequences within nursing practice and education. These clauses in the new Code, on consent and its documentation, relationships with patients, confidentiality and the meaning of inappropriate are discussed in turn in the next section, but it should be clear that these are not the only clauses inviting critique; they are examples chosen for illustrative purposes and because limited space precludes a comprehensive discussion. This is a discussion paper rather than a systematic analysis.

\section{Four clauses for concern}

\section{(1) Consent and its documentation}

The progression of the clause relating to consent through different draft versions as the new Code was developed can be seen in table 1:

\begin{tabular}{|l|l|l|}
\hline 1 & 2008 Code (clause 13) & $\begin{array}{l}\text { You must ensure that you gain consent before you begin any } \\
\text { treatment or care. }\end{array}$ \\
\hline 2 & $\begin{array}{l}\text { Consultation version } \\
\text { (clause 35) }\end{array}$ & $\begin{array}{l}\text { You must ensure that you gain appropriate and properly } \\
\text { informed consent before you begin any treatment or care, } \\
\text { ensuring that consent is documented where appropriate. }\end{array}$ \\
\hline 3 & $\begin{array}{l}\text { Draft final version pre- } \\
\text { editing (clause 4.2) }\end{array}$ & $\begin{array}{l}\text { [You must...] ensure that properly informed consent is } \\
\text { obtained and documented before any intervention requiring } \\
\text { such consent is commenced }\end{array}$ \\
\hline 4 & $\begin{array}{l}\text { Final version (clause } \\
\text { [You must...] make sure that you get properly informed } \\
\text { consent and document it before carrying out any action }\end{array}$ \\
\hline
\end{tabular}

Table 1 - Development of clause concerning consent

Consistent with law, all clauses require that consent is gained before 'any' treatment or care, though the wording 'treatment or care' has been changed to 'intervention' after consultation and to 'action' after editing. The newer versions $(\mathrm{v} 2,3,4)$ require 'properly informed consent' in place of the previous 'consent', a welcome addition. The significant point of difference is the role of documentation. The consultation version (v2) requires documentation 'where appropriate' but does not specify when. A nurse obtaining consent (which could be written, verbal or implied) for treatment or care needs to decide whether and when to document it. The clause requires that consent is obtained for any treatment or care, but that documentation is not; it is only required when appropriate, and while there is no help here for a student or registrant to decide which treatments require consent to be written or documented, it is clear that there are circumstances where consent is required but that documentation is not. Documentation clearly covers situations where written consent is required but may not where consent is verbal or implied, and where documentation is appropriate, documenting consent after the treatment, as part of documenting the treatment or care is not excluded. 
Following consultation, the version presented to Council (v3) has changed the emphasis so that consent and documentation are now initially coupled together. The need for consent before what is now referred to as 'any intervention' is clear, but the need for documentation is ambiguous. I take it that all interventions require consent and so the question of what is 'required' or not, that is something that is discretionary, can only apply to documentation. It is also clear that both consent and documentation (if it is required) must come before the treatment. I take it that the clause means that nurses and midwives must obtain properly informed consent before any intervention and that sometimes this consent needs to be documented beforehand. The final mention of consent in this clause as in 'any intervention requiring such consent is commenced' means, I assume, any intervention requiring documented consent. This meaning would be consistent with the consultation version (v2), but the tortuous syntax makes it difficult to follow, so that editing for readability is most welcome.

However, the final (published) version following editing (v4) has a different though unambiguous meaning. The problem is that it clearly says that both consent and documentation are required before any action. I take it that any action means all actions. There is no suggestion that documentation is not always required. Turning a patient in bed is an action, requiring, as it always did, properly informed consent. Now it requires documenting beforehand. A nurse is required to seek consent for the turn and document it, then perform it, then (often) document that it has been done. The clause is unambiguous yet absurd, bearing little relation to professional practice. A plausible explanation for the change in this clause is that the mangled syntax of the third version has been misinterpreted by the plain english editing process and this has not been identified at the final sign off. But whatever the reason, it is clear that a registrant or an educator cannot refer to the Code for an answer in considering the important question on how and when to document consent.

(2) Relationships with patients

\begin{tabular}{|l|l|l|}
\hline 1 & 2008 Code (clause 20) & $\begin{array}{l}\text { You must establish and actively maintain clear sexual } \\
\text { boundaries at all times with people in your care, their families } \\
\text { and carers. }\end{array}$ \\
\hline 2 & $\begin{array}{l}\text { Consultation version } \\
\text { (clause 42) }\end{array}$ & $\begin{array}{l}\text { You must maintain clear professional boundaries (including } \\
\text { sexual, personal and emotional boundaries) at all times with } \\
\text { people in your care, their families and carers. (This } \\
\text { requirement would not apply in circumstances where you need } \\
\text { to administer emergency care or treatment to an individual } \\
\text { with whom you already have a personal or familial } \\
\text { relationship.) }\end{array}$ \\
\hline 3 & $\begin{array}{l}\text { Draft final version pre- } \\
\text { editing (clause 20.6) }\end{array}$ & $\begin{array}{l}\text { [You must...] maintain objectivity and clear professional } \\
\text { boundaries at all times with people in your care (including } \\
\text { those who have formerly been in your care), their families and } \\
\text { carers. }\end{array}$ \\
\hline 4 & $\begin{array}{l}\text { Final version (clause } \\
\text { [You must...] stay objective and have clear professional } \\
\text { boundaries at all times with people in your care (including } \\
\text { those who have been in your care in the past), their families } \\
\text { and carers. }\end{array}$ \\
\hline
\end{tabular}

Table 2 - Development of clause concerning professional boundaries 
The progression of clauses concerning professional boundaries is detailed in table 2 . In restricting itself to proscribing sexual boundaries, the previous version (v1) of the Code gave little detail of the nature of professional boundaries, but it is clear that it refers to people currently receiving care. The consultation version (v2) elaborates on the nature of the boundaries so that they now include the personal and emotional. According to the consultation report [10], the section which contained this clause showed the highest level of support ( $87 \%)$ following on line consultation, but a qualitative comment was cited, concerned about use of the word 'emotional':

It's impossible not to be emotionally involved and contradicts person centered care and building relationships. It's not just being their carer...; they want someone who cares...what about in a situation where a baby dies? ...emotional should come out [sic].

$[10$, p.13]

A problem with considering sexual boundaries alongside personal and emotional boundaries is they are to be found in different places. The location of sexual boundaries can be clearly articulated because it is extremely difficult to see any sexual activity within professional relationships as being acceptable, but the same cannot be said about personal and emotional boundaries. The respondent cited above appears to have interpreted the clause as meaning that emotional and sexual boundaries are considered together and that emotional relationships are as forbidden as sexual ones, and has justifiably objected on this basis. It is unlikely that this is what the NMC intended, and possibly influenced by this comment, the wording was changed in the version presented to the Council (v3) so that the word 'professional' now covers all types of boundaries. Unlike the clause on consent, this meaning has survived the final edit. As well as use of the word 'professional' there are two significant changes between the old (v1) and the new (v4) published versions.

First the word 'objective' has been added. This is an odd word to use in relation to professional relationships. A dictionary definition [26] states that objective means 'based on real facts and not influenced by personal beliefs or feelings'. It is odd because as the respondent to the consultation observed, emotional engagement with people in our care is central to professional nursing care, much discussed in response to highly publicised poor care [6]. The UK government vision for nursing [27] is centred on compassion, based on feelings of empathy and respect. ${ }^{\mathrm{d}}$ Indeed, there is a literature which discusses love in the context of professional nursing [28], and the term 'Tender Loving Care' (TLC) is commonly used [29]. Compassionate care is not objective care. A further and wider understanding of the word objective is 'unbiased' articulated in the 'seven principles of public life' initially developed by the Nolan report ${ }^{\mathrm{e}}$ [30] but also applying to all public servants ${ }^{\mathrm{f}}$ [31]. Objectivity is explained as 'Holders of public office must act and take decisions impartially, fairly and on merit, using the best evidence and without discrimination or bias' [32, p3], but this is

\footnotetext{
${ }^{\mathrm{d}}$ Compassion is one of the $6 \mathrm{Cs}$ which defines nursing practice within the UK government strategy for nursing [27]. See Bradshaw [22] for a critique.

e The Committee on Standards in Public Life was established in 1994 in response to concerns about the ethical behaviour in members of the UK parliament. It's first report (The Nolan Report) was published the following year.

${ }_{\mathrm{f}}^{\mathrm{f}}$ In the UK, the majority of nurses are employed by the National Health Service and can be considered public servants.
} 
ambiguous for a profession which claims an advocacy role, and though the concept is problematic and contested $[4,33]$, the notion of an unbiased advocate might be considered oxymoronic. It is simply unclear what 'objective' means in the context of professional nursing care.

The second change was the inclusion of the phrase 'including those who have been in your care in the past', a significant addition not mentioned in any previous version of the Code, or the consultation version or any other UK health care professional code. In the UK, the GMC issues detailed guidance [34] on what doctors must consider before they enter into a personal relationship with former patients, but they are not excluded altogether as the NMC Code apparently requires. The GMC guidance is compatible with that issued by the Professional Standards Authority (PSA, formerly the Council for Health Care Regulatory Excellence (CHRE)), the body responsible for overseeing the UK's nine health and care professional regulatory bodies. In advice to patients and carers, it states that 'The circumstances of each healthcare professional/patient relationship are different so it is difficult to make firm rules about what is, or isn't, appropriate' [35, p.7], and while in guidance to professionals [36] it is made clear that these relationships are often inappropriate, there are also considerations given that health care professionals must take into account when using their own judgement for which they are individually accountable.

It is plausible (just) that the statement in the published version of the NMC Code implies that the boundaries are in different places for current and former patients, but arriving at this conclusion is much easier in the detailed knowledge of other published guidance, unlikely to be an option for students or registrants unless it has been pointed out to them. Read alone there is nothing in the clause to suggest that the boundaries might be in different places for current and former patients. Alternatively, it may be that there is something in the NMC's view of the philosophy of nursing practice that makes it impermissible for nurses to enter into a personal relationships with former patients, but permissible (in certain circumstances) for doctors and every other health care professional. But if there is a distinction it has not been articulated and the section of the clause about former patients was inserted after consultation rather than in response to it, so far as can be seen from consultation reports, and so has not been open to public and professional scrutiny and discussion.

Consider a registered nurse working in an accident department suturing a wound on a rugby player's leg. A month later they meet by chance in a bar and the now recovered sportsman buys the nurse a drink and asks her out on a date. Is she breaking the Code if she accepts? What if his sister asks her? Since her response may be the subject of an inquiry, the nurse might welcome the opportunity to discuss the issue with the regulator, but the facility to contact the NMC for advice has been withdrawn. She might discuss it with her professional body or her manager or even her previous university lecturer but their opinions may not influence the chair of the regulator's disciplinary panel.

\section{(3) Disclosure of confidential information.}

There has been very little change to the clause which details the circumstances in which nurses are permitted or required to breach confidentiality (see table 3), and so the analysis of the clause predates the revision of the Code. 


\begin{tabular}{|l|l|l|}
\hline 1 & 2008 Code (clause 7) & $\begin{array}{l}\text { You must disclose information if you believe someone may be } \\
\text { at risk of harm, in line with the law of the country in which } \\
\text { you are practising. }\end{array}$ \\
\hline 2 & $\begin{array}{l}\text { Consultation version } \\
\text { (clause 22) }\end{array}$ & $\begin{array}{l}\text { You must disclose information if you believe someone may be } \\
\text { at risk of harm, appropriately and in line with the law } \\
\text { regarding disclosure of information for the country in which } \\
\text { you are practising. }\end{array}$ \\
\hline 3 & $\begin{array}{l}\text { Draft final version pre- } \\
\text { editing (clause 17.2) } \\
\text { may be at risk of harm in line with the law regarding } \\
\text { disclosure of information for the country in which you are } \\
\text { practising. }\end{array}$ \\
\hline 4 & $\begin{array}{l}\text { Final version (clause } \\
\text { [You must...] share information if you believe someone may } \\
\text { be at risk of harm, in line with the laws relating to the } \\
\text { disclosure of information... }\end{array}$ \\
\hline
\end{tabular}

Table 3 Development of clause concerning disclosure of confidential information

Clause 17.2 [1] states that you must 'share information if you believe someone may be at risk of harm in line with the laws relating to the disclosure of information'. The clause further makes it clear that knowledge of the legislative framework is necessary, and in a sense this makes the clause redundant, in that it amounts to a requirement that 'you must follow the law' in regards to disclosure. There is no guidance or elaboration about the operationalisation of the clause, so that registrants as well as students and educators are required to seek clarification from elsewhere. In the light of suggestions in the introduction to the Code and comments by Kolyva [21] cited earlier about telling nurses exactly what they must do this might appear strange since the law governing disclosure is complex. A single sentence clause cannot cover all the ground and this makes it important that the wording of the clause is clear, with signposts to further information. In a guidance document discussing raising concerns [37], readers are directed to Department of Health $(\mathrm{DH})$ guidance $[38,39]$. Both the GMC and the Health and Care Professions Council (HCPC - the regulator for other health, care and psychological professionals in the UK) have clauses about confidentiality in their Codes but also substantial guidance documents [40,41]. The NMC has no such guidance document. Some professional bodies also issue guidance about confidentiality [42]. The problem for this clause is that it is misleading in four ways relating to public interest disclosure, conflicting with other important documents.

First the threshold for disclosure, under the Code's clause is a belief that someone may be at risk of harm. This is too undemanding. The GMC's guidance document, Confidentiality, states that breaches should be made in 'exceptional cases' [40, para 37], that harm must be 'likely to arise from non-disclosure of information' and that 'you must be satisfied that identifiable information is necessary for the purpose'. The GMC text suggests a much higher threshold which not only requires likelihood rather than belief in the potential for harm, but also that disclosure is necessary - a consideration absent from the NMC clause. Second, the Code requires disclosure if someone is at risk of harm. Stated like this it is possible to interpret the clause as including harm to the patient himself. The Department of Health's Supplementary guidance: Public interest disclosure [39] makes it clear that it is important to distinguish between harm to the person to whom the information relates and harm to others. Disclosure is justifiable in the latter case but not the former. 
Third, the Department of Health supplementary guidance [39] clarifies that disclosure in the public interest can only be made where there is a risk of serious harm to another person, or to prevent, detect, or prosecute, a serious crime. The earlier DH document, Confidentiality: Code of practice [38] notes that the definition of 'serious crime' is not clear and that 'the risk of child abuse or neglect, assault, a traffic accident or the spread of an infectious disease are perhaps the most common that staff may face' [38, p.35]. While there clearly cannot be a comprehensive list of harms or crimes that are considered serious, the over-simplicity of the NMC clause does not capture the fact that there is a distinction at all.

Finally, the NMC clause, like all the others, is preceded by the prescriptive 'you must' making clear its non-discretionary nature. There are some provisions in law where disclosure is required, for example the Terrorism Act 2000, and road traffic legislation [43], but for the main part and clearly explained in DH guidance [39], the law allows rather than requires disclosure. There must be a balancing of harms, uncaptured by the simple prescriptive 'you must share information...' of the NMC clause. This balancing is complex because not only must it weigh up a single act of disclosure in order to prevent serious harm to someone against harm to the patient whose information is disclosed, but also take account of the general good of maintaining a system of professional health care provision which values and protects patient confidentiality. Each case must be decided on its individual merits [38], an act assessment rather than application of a simple and unexplained rule.

\section{(4) What does inappropriate mean?}

The word 'appropriate' and its cognates appear 16 times in the NMC Code in contrast to 5 times in the much longer Good Medical Practice, and can be found, for example, in the clause relating to the expression of personal beliefs. The need for this clause was not identified in the Francis report or the NMC in its accounts of the changes, and there is no comparable clause in the 2008 version.

\begin{tabular}{|l|l|l|}
\hline 1 & 2008 Code (clause 20) & No equivalent clause \\
\hline 2 & $\begin{array}{l}\text { Consultation version } \\
\text { (clause 94) }\end{array}$ & $\begin{array}{l}\text { You must ensure that you do not express your personal beliefs } \\
\text { (including political, religious or moral beliefs) to people in a } \\
\text { way that may exploit their vulnerability or cause them upset or } \\
\text { distress. }\end{array}$ \\
\hline 3 & $\begin{array}{l}\text { Draft final version pre- } \\
\text { editing (clause 20.7) }\end{array}$ & $\begin{array}{l}\text { [You must...] not express your personal beliefs (including } \\
\text { political, religious or moral beliefs) to people in an } \\
\text { inappropriate manner }\end{array}$ \\
\hline 4 & $\begin{array}{l}\text { Final version (clause } \\
20.7)\end{array}$ & $\begin{array}{l}\text { [You must...] make sure you do not express your personal } \\
\text { beliefs (including political, religious or moral beliefs) to } \\
\text { people in an inappropriate way }\end{array}$ \\
\hline
\end{tabular}

Table 4 - Development of clauses relating to the expression of personal belief

The consultation version precluded expressions of personal belief if they 'may exploit' vulnerability or cause upset or distress, echoing, with very minor differences, the clause in the GMC's Good Medical Practice supported by additional guidance [44]. Following consultation the clause has been changed, so that it is now forbidden to express beliefs in an 'inappropriate' way. The word 'inappropriate' is frequently used to mean unsuitable or improper [26], but there is no ground given as to what is inappropriate in this context. While 
the GMC version, (substantially the same as NMC's consultation version), is itself open to interpretation, there are at least criteria upon which a judgement can be made. In the final version, the word 'inappropriate' offers circularity in place of criteria; the clause amounts to a sentence which states that 'You must not do that which is not suitable'. Here as in the previous discussions, the clause can only be clearly understood, and therefore act as an action guide, if explained and elaborated upon. Further guidance is needed and the NMC fails to provide it.

\section{Where has all the guidance gone?}

A feature of the clauses examined in this paper is that meaning is vague, or where it is clear it is also implausible. The clauses that I have discussed in detail are concerned with the complexity of professional practice, and so if they are to meet their purpose, they must be augmented by explanations and guidance. Drawing upon NMC documents, including its response to a Law Commissions consultation, I argue in the final section of the paper that the NMC position on guidance is contradictory and has changed significantly so that the provision of the explanatory guidance that would enable the Code to fulfil its stated purpose now occupies a low priority.

As part of a strategy to improve health care professional regulation, the UK government commissioned a simplification review of the legislative framework, "with a view to giving greater autonomy to the regulatory bodies to decide how best to meet their statutory duties.' [45, p.13]. The review was undertaken by the Law Commissions, ${ }^{\mathrm{g}}$ statutory independent bodies with the function of keeping the law under review, ensuring that it is 'fair, modern, simple and as cost effective as possible' [46]. The intention was that legislation would follow during the lifetime of the Parliament (that is before May 2015), but this did not happen, and to the 'deep disappointment' of the NMC [47] the legislative programme set out by the incoming conservative government has not yet $\left(1^{\text {st }}\right.$ September 2015$)$ identified a timetable for enacting draft legislation produced as part of the final report. Nevertheless the draft Bill attracted wide support, including from the NMC [48,49] and so it can be considered, alongside its accompanying consultation documents and responses as an authoritative source. The review and draft legislation are possibly most important for the proposed simplification of procedure in fitness to practice cases, but all aspects of regulation are covered, including the provision of guidance. The consultation document noted concerns about the quality of some guidance issued by regulators, but the provisional proposal was that regulators should be required to produce guidance. The Commissioners' view, expressed in para 6.68, was that:

This should be a duty and not a power because the issuing of such guidance is an essential part of the regulatory role, and it would not be acceptable for a regulator to decide not to issue any guidance in relation to the standards it is responsible for enforcing.

There was no intention for legislation to require guidance on specific subjects which was to remain at the discretion of regulators. The NMC response on the issue of guidance stated that:

\footnotetext{
${ }^{\mathrm{g}}$ The review was jointly undertaken by the Law commission, The Scottish Law Commission and the Northern Ireland Law Commission
} 
We would not wish to see limits on the guidance issued by regulators. Neither should there be a presumption that if a topic is considered elsewhere, for example through NICE standards or workplace guidelines, it should not also be the subject of guidance from regulators. The 'contract' between a regulator and its registrants demands that registrants have a right to clarity about which aspects of practice are critical to their continued registration.

$[20$, p.31]

On the specific point of whether the proposed legislation should require or allow regulators to issue guidance, the NMC response was clear:

We agree that regulators should be required to issue guidance for professional conduct and practice. This is the means by which the assurance provided by professional registration is made manifest to the public, and by which registrants understand how they can remain in good standing.

$[20$, p.31]

Support for a requirement was described as an 'overwhelming majority' in the Law Commissions' report [51] on the consultation response, with 44 of the 46 responses which expressed a view agreeing with the proposal. However, despite this clear support for required guidance in both the initial proposal and consultation responses, and without explanation for the change, the final report [23] allows rather than requires regulators to issue guidance. Clause 108(6) of the draft legislation states that 'a regulatory body may issue guidance about the standards'. The UK government accepted this in principle [52].

While the NMC's view was very clearly in favour of the need for guidance generally, and that it should be a legal requirement, there is no indication at this time of whether it considered that it provided too much guidance or not enough. When the Council approved the revised Code, the accompanying paper presented [11] also briefly considered the issue of guidance, including that guidance development will need to satisfy these criteria:

- Guidance is necessary to meet public protection needs.

- Guidance must relate directly to the Code and/or our standards.

- Guidance must be proportionate and in line with PSA principles on 'right touch' regulation.

- Where relevant and appropriate we will seek to develop guidance in conjunction with other regulators or professional bodies.

Neither the origins nor the rationale of the criteria is clear. I have argued that guidance is necessary in the areas discussed earlier because meaning is unclear, and this satisfies the first criterion if clarity of meaning is required for public protection. The PSA principles referred to concern regulation rather than guidance, and the only use of the word 'guidance' in the document [53] refers to employers' policies and guidance. A further NMC board paper, Guidance underpinning the Code [54] presented to the January 2015 Council meeting states 
that it is 'our position that the NMC should reduce the guidance it issues underpinning the Code to a limited number of key areas'. The minutes of this meeting state that:

The Council noted that, as part of the consultation to inform revisions to the Code, a broad consensus had emerged that the Code should be a comprehensive document and that the numbers of supporting guidance documents should be relatively small. The revised Code took into account those views.

Though the NMC clearly supported published guidance for clarity, and the enactment of a legal requirement to issue guidance, it withdrew some guidance at the time of issuing the Code, compounding the previous discontinuation of advice documents and a telephone advice service, and has subsequently made it clear that its policy is to keep guidance to a minimum. Consultation on the issuing and revision of guidance is a requirement of both the nursing and midwifery order 2001 and the draft legislation presented by the Law Commissions. ${ }^{\text {h }}$ However, under existing law, consultation is not required prior to the withdrawal of guidance. Though NMC minutes claimed that during consultation a consensus emerged that there should be a relatively small amount of guidance [55], there is no trace of this view in the report of the consultation [10] or either of the two board papers [12, 54] concerning the revision of the Code or its underpinning guidance.

The NMC position appears to have changed significantly. Perhaps this is not surprising given the recent history of poor performance by the NMC and the remedial action planning that followed [56, 57]. A strategic review of the NMC commissioned by the government and undertaken by the CHRE in 2012 found that the NMC had lost sight of its core function:

There still are frequent calls from its registrants, reported in the media, for it [the $\mathrm{NMC}$ ] to take the lead on particular professional matters or to produce specialist areas of guidance. In our view, this blurs the boundaries between regulation and professional development, confuses responsibilities and risks a duplication of effort and resource which is neither helpful to the professions of nursing and midwifery nor ultimately the public.

However, the review also issued a clear statement of a regulator's primary role:

A core part of a regulator's role is to define the standards which its registrants must adhere to and to help them understand how those standards apply in their daily practice.

Guidance issued in pursuit of a core role clearly relates to regulation rather than development of the profession, and it is clear that without guidance the regulator's role as articulated by

\footnotetext{
${ }^{\mathrm{h}}$ The draft legislation at 249(6) allowed regulators to dispense with this requirement with the agreement of the PSA. The Government response accepted that the requirement to consult could be dispensed with where the regulator considered it disproportionate or inappropriate but did not agree that this decision should need the agreement of the PSA. It did however give some examples where this would be appropriate: 'to provide clarification, correcting a mistake or bringing a document in line with other legislation’ ([52], p.21)
} 
the review is not achieved. It is easy, however, to feel some sympathy for the NMC on the point of development of the profession. The Interim CHRE report criticised the NMC for becoming distracted by projects unsupportive of its primary function, including campaigning for the statutory regulation of health care support workers. The report rather disdainfully dismissed these projects as '....ambitions for expansion and influence' [56, p.47] and yet the recommendation that the NMC do precisely this was a significant part of the Francis Report [6] the following year.

As I have demonstrated, some clauses in the Code cannot be meaningfully understood in their present form and so the view that guidance is not needed because the Code is a comprehensive document in itself is simply not credible, and inconsistent with views expressed earlier in response to the Law Commissions' proposals. Other health care regulators in the $\mathrm{UK}$, for example the $\mathrm{GMC}^{\mathrm{i}}$, issue comprehensive guidance on a wide range of issues. Nursing regulators in other countries also provide comprehensive guidance or interpretative statements. The American Nurses Association Code of Ethics with Interpretative Statements [58] is 76 pages long and the Irish code [59] is also more comprehensive and supported by numerous guidance documents. While there clearly is the possibility that too much guidance obfuscates rather clarifies [60, 61], the NMC minimalist position on the provision of guidance is unconventional compared with others, leaving registrants unable to ascertain action guiding meaning from ambiguous clauses in the Code and educators unable to use it in teaching.

\section{Conclusion}

There is a conceptual problem at the heart of this analysis: Presented as it is, shorn of clarifying guidance, the Code simply cannot tell nurses exactly what they must do. It can set out in broad terms using simple principles what people can expect, but to attempt any more than this is seriously to over-simplify the complex environment in which nurses and other health care professionals operate. Most other UK regulators recognise this. In the drafting of the new code, the NMC has compounded conceptual confusion by allowing a series of errors and ambiguities, illustrated by the four examples discussed in this paper. Following Pattison and Wainwright [3], I conclude with the observation that though it might seem churlish to criticise the code, especially in light of the considerable effort expended on consultation and development, it is difficult not to criticise the process which has led to the publication of such a flawed document.

The situation can be remedied to some extent by a clarification of the currently contradictory position on guidance. If the Code is to meet its stated aim then guidance must be provided on a number of issues not least those identified in the paper. At the very least the NMC should make it clear which guidance from other organisations is considered authoritative and capable of being taken into account by fitness to practice hearings. The NMC [20] was open to the proposition that regulators collaborate on guidance, for example joint NMC/GMC guidance on the duty of candour [62] and on further matters like confidentiality where legal standards apply to all health care professions, further collaborative work would clarify the situation.

\footnotetext{
${ }^{\text {i }}$ A full list can be found at http://www.gmc-uk.org/guidance/ethical_guidance.asp
} 
Despite its lengthy gestation, the current code does not meet its function, and needs further corrective revision and the provision of explanatory guidance so that it does.

\section{Acknowledgments}

I gratefully acknowledge the support and helpful comments of Iain Snelling, Martin Lipscomb and John Paley on earlier drafts of this paper.

\section{Declaration of conflicting interests}

The Author declares that there is no conflict of interest. 


\section{References}

[1] Nursing and Midwifery Council. The Code: Professional Standards of practice and behaviour for nurses and midwives. London: Nursing and Midwifery Council.

http://www.nmc.org.uk/globalassets/sitedocuments/nmc-publications/revised-new-nmc-code.pdf (2015, accessed $1^{\text {st }}$ September 2015)

[2] Pattison S. (2001). Are nursing codes of practice ethical? Nurs Ethics 2001; 8(1), 5-18.

[3] Pattison S and Wainwright P. Is the 2008 NMC Code ethical? Nurs Ethics 2010; 17(1), 9-18.

[4] Seedhouse D. Practical Nursing Philosophy: The universal ethical code. Chichester: Wiley, 2000.

[5] Francis R. Independent inquiry into care provided by Mid Staffordshire NHS Foundation Trust January 2005 - March 2009. London: The Stationary Office, 2010

[6] Francis R. Report of the Mid Staffordshire NHS Foundation Trust Public Inquiry. London: The Stationary Office, 2013.

[7] Nursing and Midwifery Council. The Code: Standards of Conduct Performance and Ethics for Nurses and Midwives. London: Nursing and Midwifery Council http://www.nmc.org.uk/globalassets/sitedocuments/standards/the-code-a4-20100406.pdf (2008, accessed $1^{\text {st }}$ September 2015)

[8] Nursing and Midwifery Council. NMC Response to the Francis Report. London Nursing and Midwifery Council http://www.nmc.org.uk/globalassets/siteDocuments/Francis-report/NMC-responseto-the-Francis-report-18-July.pdf $\left(2013\right.$, accessed $1^{\text {st }}$ September 2015)

[9] Nursing and Midwifery Council. The Code: Standards of Conduct Performance and Ethics for Nurses and Midwives - Draft revised version. London: Nursing and Midwifery Council

http://eoe.hee.nhs.uk/files/2014/04/Draft-revised-code.pdf $\left(2014\right.$, accessed $1^{\text {st }}$ September 2015)

[10] Nursing and Midwifery Council Code Evidence Report. London: Nursing and Midwifery Council [on line] http://www.nmc.org.uk/globalassets/siteDocuments/Consultations/2014/Code-evidence-report.pdf (2014, accessed $1^{\text {st }}$ September 2015)

[11] Nursing and Midwifery Council. The Code: Professional Standards of practice and behaviour for nurses and midwives draft version. Presented in board papers for council meeting $3^{\text {rd }}$ December 2014 , Annexe 1 to item 11, pp $187-200$.

http://www.nmc.org.uk/globalassets/sitedocuments/councilpapersanddocuments/council-2014/councilpapers-20141203-final-pdf.pdf $\left(2014\right.$, accessed $1^{\text {st }}$ September 2015)

[12] Nursing and Midwifery Council. Revision of the Code. Presented in board papers for council meeting $3^{\text {rd }}$ December 2014, item 11, pp 177- 185

http://www.nmc.org.uk/globalassets/sitedocuments/councilpapersanddocuments/council-2014/councilpapers-20141203-final-pdf.pdf (2014, accessed $1^{\text {st }}$ September 2015)

[13] Plain English Campaign (2015) Crystal mark. http://www.plainenglish.co.uk/services/crystalmark.html $\left(2015\right.$, accessed $1^{\text {st }}$ September 2015)

[14] Nursing and Midwifery Council. Minutes of the Council meeting of $3^{\text {rd }}$ December 2014. Presented in Board papers for council meeting $28^{\text {th }}$ January 2015 item 15 , pp 5-16.

http://www.nmc.org.uk/globalassets/sitedocuments/councilpapersanddocuments/council-2015/council28-january-2015-agenda-papers-final.pdf $\left(2015\right.$, accessed $1^{\text {st }}$ September 2015)

[15] Nursing and Midwifery Council. Introducing the revised NMC Code: PowerPoint presentation. London: Nursing and Midwifery Council. http://www.nmc.org.uk/standards/code/ $\left(2015\right.$, accessed $1^{\text {st }}$ September 2015) 
[16] Dix A. Changes introduced into the revised NMC code. Nursing Times 2015; 111(6): 22-23.

[17] Scammell J. Values: The heart of our professional code. British Journal of Nursing 2014; 23(19): 1048

[18] Sutcliffe H. Understanding the NMC code of conduct: a student perspective. Nursing Standard 2011; 25(52): 35-39.

[19] Royal College of Nursing. Royal College of Nursing response to Nursing and Midwifery Council's consultation on a draft revised code and our proposed approach to revalidation. London: Royal College of Nursing http://www.rcn.org.uk/_data/assets/pdf_file/0008/588365/44_14_RCN_response_NMC_a_draft_revis ed_code and our_proposed approach to revalidation.pdf $\left(2014\right.$, accessed $1^{\text {st }}$ September 2015)

[20] Nursing and Midwifery Council NMC Response to a joint consultation paper issued by the law Commission, Scottish Law Commission and Northern Ireland Law Commission on $1^{\text {st }}$ March 2012. London: Nursing and Midwifery Council (2012)

[21] Kolyva K. Patients and clinicians have their say in the new NMC code. Journal of Community Nursing 2014; 28(4): 20.

[22] Bradshaw, A. An analysis of England's nursing policy on compassion and the 6Cs: the hidden presence of M. Simone Roach's model of caring. Nursing Inquiry Epub ahead of print $8^{\text {th }}$ June 2015 DOI: 10.1111/nin. 12107

[23] Law Commission, Scottish Law Commission, Northern Ireland Law Commission Regulation of Health Care Professionals; Regulation of Social Care Professionals in England. London: Law Commission http://lawcommission.justice.gov.uk/docs/lc345 regulation_of healthcare_professionals.pdf $(2014$, accessed $1^{\text {st }}$ September 2015).

[24] Nursing and Midwifery Council. Standards and guidance review cycle 2014/2017. Presented in board papers for council meeting $26^{\text {th }}$ March 2014, item 10, pp 111-112 http://www.nmc.org.uk/globalassets/siteDocuments/CouncilPapersAndDocuments/Council2014/Council-papers---OPEN-26-March-2014-FINAL.pdf (2014, accessed $1^{\text {st }}$ September 2015).

[25] General Medical Council Good Medical Practice. http://www.gmcuk.org/static/documents/content/Good_medical_practice_-_English_0914.pdf $\left(2013\right.$, accessed $1^{\text {st }}$ September 2015).

[26] Cambridge Dictionaries on-line http://dictionary.cambridge.org/ (2015, accessed $1^{\text {st }}$ September 2015).

[27] Department of Health. Compassion in Practice. Nursing, Midwifery and Care Staff: Our Vision and Strategy. London: Department of Health http://www.england.nhs.uk/wpcontent/uploads/2012/12/compassion-in-practice.pdf (2012, accessed $1^{\text {st }}$ September 2015).

[28] Arman M, and Rehnsfeldt A. The presence of love in ethical caring. Nursing forum 2006; 41( 1): 4-12.

[29] Kendrick KD and Robinson S. 'Tender Loving Care' as a relational ethic in nursing practice. Nurs Ethics 2002; 9(3): 291-300.

[30] Nolan MP. Standards in public life in public life. First report of the committee on Standards in public life. London: HMSO, 1995.

[31] Baillie L and Black S. Professional Values in Nursing. London: CRC Press, 2015.

[32] Committee on Standards in Public life. Ethical standards for providers of public services. London: Committee on Standards in Public life https://www.gov.uk/government/uploads/system/uploads/attachment_data/file/336942/CSPL_EthicalSt andards_web.pdf $\left(2014\right.$, accessed $1^{\text {st }}$ September 2015). 
[33] Cole C, Wellard S and Mummery J. Problematising autonomy and advocacy in nursing. Nurs Ethics, 2014; 21(5): 576-582.

[34] General Medical Council. Maintaining a professional boundary between you and your patient. London: General Medical Council. http://www.gmc-

uk.org/static/documents/content/Maintaining_a_professional_boundary_between_you_and_your_patie nt.pdf $\left(2013\right.$, accessed $1^{\text {st }}$ September 2015).

[35] Council for Healthcare Regulatory Excellence. Clear sexual boundaries between healthcare professionals and patients. Information for patients and carers.

http://www.professionalstandards.org.uk/docs/psa-library/guidance-for-patients---clear-sexualboundaries-with-health-professionals.pdf?sfvrsn $=0$ (2009, accessed $1^{\text {st }}$ September 2015).

[36] Council for Healthcare Regulatory Excellence. Clear sexual boundaries between healthcare professionals and patients: responsibilities of healthcare professionals http://www.professionalstandards.org.uk/docs/default-source/psa-library/responsibilities-of-healthcareprofessionals---clear-sexual-boundaries.pdf?sfvrsn $=0$ (2008, accessed $1^{\text {st }}$ September 2015).

[37] Nursing and Midwifery Council. Raising concerns: Guidance for nurses and midwives. http://www.nmc.org.uk/globalassets/sitedocuments/annual_reports_and_accounts/raising-concerns-10june-2015-2.pdf (2015, accessed $1^{\text {st }}$ September 2015).

[38] Department of Health. Confidentiality: NHS Code of Practice. http://www.ecric.nhs.uk/docs/nhs_conf_code.pdf (2003, accessed $1^{\text {st }}$ September 2015).

[39] Department of Health. Confidentiality: NHS Code of Practice. Supplementary Guidance: Public Interest Disclosures. https://www.gov.uk/government/publications/confidentiality-nhs-code-ofpractice-supplementary-guidance-public-interest-disclosures (2010, accessed $1^{\text {st }}$ September 2015).

[40] General Medical Council. Confidentiality. London: General Medical Council. http://www.gmcuk.org/static/documents/content/Confidentiality__English_0914.pdf (2009, accessed $1^{\text {st }}$ September 2015).

[41] Health and Care Professions Council. Confidentiality - guidance for registrants. London: Health and Care Professions Council. http://www.hpcuk.org/assets/documents/100023F1GuidanceonconfidentialityFINAL.pdf $\left(2012\right.$, accessed $1^{\text {st }}$ September 2015).

[42] British Medical Association. Confidentiality and disclosure of health information tool kit. http://bma.org.uk/practical-support-at-work/ethics/confidentiality-and-health-records/confidentialitytool-kit (no date, accessed $1^{\text {st }}$ September 2015).

[43] Brazier M and Cave E. Medicine, Patients and the Law (fifth edition). London: Penguin, 2011.

[44] General Medical Council. Personal beliefs and medical practice London: General Medical Council. http://www.gmc-uk.org/Personal_beliefs_and_medical_practice.pdf_58833376.pdf $\left(2013\right.$, accessed $1^{\text {st }}$ September 2015).

[45] Secretary of state for Health. Enabling Excellence: Accountability for healthcare workers, social workers and social care workers. London: The Stationery Office https://www.gov.uk/government/publications/enabling-excellence-autonomy-and-accountability-forhealth-and-social-care-staff (2011, accessed $1^{\text {st }}$ September 2015).

[46] Law Commission. About Us. http://lawcommission.justice.gov.uk/about-us.htm (no date, accessed $1^{\text {st }}$ September 2015).

[47] Nursing and Midwifery Council. Queen's Speech briefing - the importance of a Bill modernising health professional regulation. London: Nursing and Midwifery Council.

http://www.nmc.org.uk/globalassets/sitedocuments/press/queens-speech-briefing--the-importance-of-abill-modernising-health-professional-regulation.pdf $\left(2015\right.$, accessed $1^{\text {st }}$ September 2015). 
[48] Smith J. Bill needs push to sweep away 'inflexible' healthcare regulation framework. The Guardian, http://www.theguardian.com/healthcare-network/2014/apr/07/law-commission-bill-published-thisweek $\left(2014\right.$, accessed $1^{\text {st }}$ September 2015).

[49] Nursing and Midwifery Council. Better legislation for better regulation: the case for legislative reform. London: Nursing and Midwifery Council

http://www.nmc.org.uk/globalassets/sitedocuments/press/better-legislation-for-better-regulation---thenmcs-case-for-legislative-reform.pdf (2014, accessed $1^{\text {st }}$ September 2015).

[50] Law Commission, Scottish Law Commission, Northern Ireland Law Commission Joint Consultation Paper LCCP 202 / SLCDP 153 / NILC 12 (2012); Regulation of health care professionals: Regulation of social care professionals in England. London: Law Commission.

http://lawcommission.justice.gov.uk/docs/cp202_regulation_of_healthcare_professionals_consultation. pdf (2012, accessed $1^{\text {st }}$ September 2015).

[51] Law Commission, Scottish Law Commission, Northern Ireland Law Commission Joint Consultation Paper LCCP 202 / SLCDP 153 / NILC 12 (2012) (Consultation Analysis); Regulation of health care professionals: Regulation of social care professionals in England. Consultation analysis. London: Law Commission.

http://lawcommission.justice.gov.uk/docs/cp202_regulation_of_healthcare_professionals_analysis-ofresponses_complete.pdf $\left(2013\right.$, accessed $1^{\text {st }}$ September 2015).

[52] Department of Health. Regulation of Health Care Professionals Regulation of Social Care Professionals in England: The Government's response to Law Commission report 345, Scottish Law Commission report 237 and Northern Ireland Law Commission report 18 Cm 8839 SG/2014/26 Cm https://www.gov.uk/government/uploads/system/uploads/attachment_data/file/399020/Response_Cm_ 8995.pdf $\left(2014\right.$, accessed $1^{\text {st }}$ September 2015).

[53] Professional Standards Authority. Right touch regulation http://www.professionalstandards.org.uk/docs/default-source/psa-library/right-touchregulation.pdf?sfvrsn=0 (2010, accessed $1^{\text {st }}$ September 2015).

[54] Nursing and Midwifery Council. Guidance underpinning the Code. Presented in Board papers for council meeting $28^{\text {th }}$ January 2015 item 15 , pp $159-162$.

http://www.nmc.org.uk/globalassets/sitedocuments/councilpapersanddocuments/council-2015/council28-january-2015-agenda-papers-final.pdf (2015, accessed $1^{\text {st }}$ September 2015).

[55] Nursing and Midwifery Council. Minutes of the Council meeting of $28^{\text {th }}$ January 2015. Presented in Board papers for council meeting $25^{\text {th }}$ March 2015, pp 5-18 http://www.nmc.org.uk/globalassets/sitedocuments/councilpapersanddocuments/council-2015/councilpdf-20150325-final.pdf (2015, accessed $1^{\text {st }}$ September 2015).

[56] Council for Healthcare Regulatory Excellence. Special report to the Minister of State for Health Services on the Nursing and Midwifery Council London: Council for Healthcare Regulatory Excellence http://www.nmc.org.uk/globalassets/siteDocuments/CHRE/CHRE-Special-report-NMC-2008.pdf (2008, accessed $1^{\text {st }}$ September 2015).

[57] Council for Healthcare Regulatory Excellence. Strategic review of the Nursing and Midwifery Council: Final report. London: Council for Healthcare Regulatory Excellence http://www.professionalstandards.org.uk/docs/special-reviews-and-investigations/chre-final-report-for$\underline{\text { nmc-strategic-review-(pdf).pdf?sfvrsn }=0}$ (2012, accessed $1^{\text {st }}$ September 2015).

[58] American Nurses Association. Code of ethics for nurses with interpretive statements. http://www.nursingworld.org/MainMenuCategories/EthicsStandards/CodeofEthicsforNurses/Code-ofEthics-For-Nurses.html (2015, accessed $1^{\text {st }}$ September 2015).

[59] Nursing and Midwifery Board of Ireland Code of professional conduct and ethics http://www.nursingboard.ie/en/code/new-code.aspx (2014, accessed $1^{\text {st }}$ September 2015). 
[60] Eriksson S, Hogland AT and Helgesson G. Do ethical guidelines give guidance? A critical examination of eight ethics regulations. Camb Q Healthc Ethic 2008; 17:15-29

[61] Professional Standards Authority. Rethinking regulation. London: Professional Standards Authority http://www.professionalstandards.org.uk/docs/default-source/psa-library/rethinkingregulation.pdf?sfvrsn=2 $\left(2015\right.$, accessed $1^{\text {st }}$ September 2015)

[62] Nursing and Midwifery Council / General Medical Council. Openness and honesty when things go wrong: the professional duty of candour http://www.nmc.org.uk/globalassets/sitedocuments/nmcpublications/openness-and-honesty-when-things-go-wrong--the-professional-duty-of-candour.pdf (2015, accessed $1^{\text {st }}$ September 2015). 